\title{
The effect of company financial performance and company characteristics on Greenhouse Gas (GHG) Emission Disclosure
}

\author{
Indah Fajarini Sri Wahyuningrum ${ }^{1, *}$, Hadrian Djajadikerta ${ }^{2}$, and Ema Suprapti $^{1}$ \\ ${ }^{1}$ Department of Accounting, Faculty of Economics, Semarang State University, Semarang - Indonesia \\ ${ }^{2}$ School of Business, Edith Cowan University, Joondalup, Western Australia - Australia
}

\begin{abstract}
This study aims to examine the effect of company financial performance (profitability), company characteristics (PROPER rating, firm size, and institutional ownership) on Greenhouse Gas (GHG) emission disclosure using all listed companies in Indonesia Stock Exchange in from 2015 to 2017. The GHG emission disclosure variable is measured using the disclosure index approach. The result indicates that on average, the total number of companies disclose their GHG emission disclosure is increased from $30 \%$ in 2015 to $32 \%$ in 2017 , even though the disclosure of GHG emissions is still relatively low. On average, in this study, companies as a sample are in a "blue" rating of PROPER rating (which have value 3 out of 4). The most disclosed item by companies is external verification with $92 \%$ in 3 years. The results point out that profitability, PROPER rating, and institutional ownership positively affect the GHG emission disclosure. However, the firm size was not indicated to affect GHG emission disclosure. This study also gives a contribution to the GHG emission disclosure literature by providing factors that affect companies' GHG emission disclosure, particularly in Indonesia.
\end{abstract}

Keywords: Greenhouse gas disclosure; Profitability; Proper rating.

\section{Introduction}

\subsection{Background}

Climate change has become major attention to all parties worldwide. One of the contributors to climate change is greenhouse gas that elevates global temperature [1]. The negative impacts of greenhouse gas have attracted various comments on the balance between economic development and environmental protection [2]. Some countries, like Japan, England, Canada, the European Union, New Zealand, and South Korea have started to act upon greenhouse gas issues by enforcing new regulations. These countries began mandating the disclosure of environmental performance to be reported by companies in their financial statements.

Following those developed countries, Indonesia also takes actions to decrease greenhouse gas emissions. New regulations regarding greenhouse gas have been released for example Presidential Decree No. 61 and No.71 of 2011. Besides, the government, through the Ministry of Environment, encourages companies to carry out environmental management by issuing Company Performance Rating Assessment Program (PROPER). However, since environmental performance disclosure is still largely voluntary, it is not prioritized by many Indonesia companies.

There are five levels in this rating, which are gold, green, blue, red, and black. Gold rating is given to companies that are consistent in carrying out environmental management and ethical business. Green rating is given to companies that put extra effort into environmental management. Blue rating is given to companies that carry out environmental management as per requirements. Red rating is given when the environmental management efforts performed do not meet the requirements. The lowest rating, black, is given to companies that deliberately commit negligence resulting in environmental damage. It is interesting to look closely at the internal and external factors of companies that are supposed to have impacts on $\mathrm{GHG}$ emission disclosure.

Therefore, this study aims to examine the effect of profitability, PROPER rating, firm size, and institutional ownership on GHG emission disclosure. This study becomes interesting with the inclusion of PROPER rating variable that is supposed to affect GHG emission disclosure. PROPER rating is an environmental performance assessment issued by the Ministry of Environment as a form of appreciation to companies for their environmental performance.

\subsection{Theoretical Framework}

Stakeholder theory states that companies have responsibilities to several parties, namely shareholders and stakeholders and that companies should focus more on the environment and long term sustainable

\footnotetext{
* Corresponding author: i.fajarini@mail.unnes.ac.id
} 
development [3]. This theory holds that the existence of a company is determined by stakeholders, thus the company needs to maintain its relationship with stakeholders so as not to interfere with the achievement of company goals, which is by GHG emission disclosure. The disclosure can be employed as a manifestation of information disposal to stakeholders on their performance on social, economic and environmental aspects.

Legitimation theory states that companies must ensure that their activities are acceptable to external parties [3]. Furthermore, company operational activities carried out by the company must be in the frame and norms that exist in society and the environment in which the company operates. Companies use performance and environment-related disclosures as an effort to justify the company's operations without endangering the environment [4].

\subsection{Hypotheses}

\subsubsection{Profitability}

As mentioned before, the legitimation theory states that company activities must be acceptable to the community such as upholding environmental responsibilities [5]. High-profit companies possess more than enough resources to perform their responsibilities to the environment in the form of GHG emission disclosure. It can be used to mitigate social pressure from the community and as a form of positive company signals to stakeholders. A study by [6-9] showed that profitability has significant and positive effects on GHG emission disclosure.

H1: High-profit companies will put extra effort into GHG emission disclosure compared to companies with lower profitability.

\subsubsection{PROPER rating}

PROPER is an environmental performance evaluation program for a company. The stakeholder theory holds that the company is not only responsible for its interests but also responsible for the environment. The better the PROPER rating of a company, the better the environmental performance of a company. Companies with better PROPER rating tend to have broader disclosure, including GHG emission disclosure. Even though it is voluntary in nature, it is well intended to provide information to stakeholders. A study conducted by [10], [11] showed that the PROPER rating had a significant impact on GHG emission disclosure.

H2: Companies with better PROPER rating will provide better GHG emission disclosure compared to companies with lower PROPER rating.

\subsubsection{Firm Size}

According to legitimation and stakeholder theories, big companies will no doubt gather big public attention.
Consequently, social pressure from the community will also rise. Furthermore, big companies have more shareholders than small companies and these shareholders may be interested in corporate social activities. These activities may be used by companies to make public disclosures related to their environmental performance to mitigate existing social pressure. Previous studies, such as [12-14] found that firm size has a positive influence on GHG emission disclosure.

H3: Bigger companies will perform higher GHG emission disclosure compared to smaller companies.

\subsubsection{Institution Ownership}

Institutional ownership is the percentage of the company's shares owned by institutions. Companies with high institutional ownership can increase supervision over the disclosure of all company activities including environmental performance in the form of GHG emission disclosure. This is done to boost the positive image of the stakeholders. In a study conducted by [15], institutional ownership has a positive effect on GHG emission disclosure. This finding is supported by [16] proves that institutional ownership has a positive influence on environmental disclosure.

H4: Companies with bigger institutional ownership will perform higher GHG emission disclosure compared to companies with smaller institutional ownership.

\section{Research methods}

\subsection{Sampling and Data Collection}

Data is obtained from sustainability reports and annual reports from all companies listed on the Indonesia Stock Exchange in 2015-2017. The sample was selected using a purposive sampling method to obtain 25 companies. The sample selection criteria are shown in Table 1 as follows:

Table 1. Sample Selection Criteria

\begin{tabular}{|l|c|}
\hline \multicolumn{1}{|c|}{ Criteria } & Sample Number \\
\hline $\begin{array}{l}\text { Companies listed in Indonesia Stock } \\
\text { Exchange in 2018 }\end{array}$ & 654 \\
\hline $\begin{array}{l}\text { Non PROPER Companies (2015- } \\
\text { 2017) }\end{array}$ & $(609)$ \\
\hline $\begin{array}{l}\text { Companies without institutional } \\
\text { ownership }\end{array}$ & $(15)$ \\
\hline $\begin{array}{l}\text { Companies that do not disclose } \\
\text { complete information }\end{array}$ & $(5)$ \\
\hline Companies used for samples & 25 \\
\hline Total sampled used (2015-2017) & 75 \\
\hline
\end{tabular}

\subsection{Variable Measurement and Analysis}

The dependent variables in this study are GHG emission disclosure. GHG emission disclosure variable is measured by the disclosure index approach by scoring each disclosure item 1 for disclosure and 0 for no disclosure. The total score is divided by the total item 
which is 18. Each item in GHG emission disclosure is presented in Table 2 as follows:

Table 2. GHG Emission Disclosure Checklist

\begin{tabular}{|c|c|c|}
\hline Category & Code & Item \\
\hline $\mathrm{CC}$ & $\begin{array}{l}\mathrm{CC} 1 \\
\mathrm{CC} 2\end{array}$ & $\begin{array}{l}\text { 1. Assessment of risks and } \\
\text { opportunities } \\
\text { 2. Financial implications }\end{array}$ \\
\hline $\mathrm{GH}$ & $\begin{array}{l}\text { GH1 } \\
\text { GH2 } \\
\text { GH3 } \\
\text { GH4 } \\
\text { GH5 } \\
\text { GH6 } \\
\text { GH7 } \\
\end{array}$ & $\begin{array}{l}\text { 3. Methodology for calculation } \\
\text { 4. External verification } \\
\text { 5. Total emissions } \\
\text { 6. Disclosure by scope } \\
\text { 7. Disclosure by source } \\
\text { 8. Disclosure by facility or segment } \\
\text { 9. Historical comparison of emissions }\end{array}$ \\
\hline EC & $\begin{array}{l}\text { EC1 } \\
\text { EC2 } \\
\text { EC3 }\end{array}$ & $\begin{array}{l}\text { 10. Total consumed } \\
\text { 11. Disclosure consumption from } \\
\text { renewable source } \\
\text { 12. Disclosure by type, facility, or } \\
\text { segment }\end{array}$ \\
\hline $\mathrm{RC}$ & $\begin{array}{l}\mathrm{RC} 1 \\
\mathrm{RC} 2 \\
\mathrm{RC} 3 \\
\mathrm{RC} 4\end{array}$ & $\begin{array}{l}\text { 13. Plans to reduce GHG emissions } \\
\text { 14. Targets for GHG emissions } \\
\text { 15. Reductions achieved to date } \\
\text { 16. Costs of future emissions factored } \\
\text { in capital expenditure planning }\end{array}$ \\
\hline $\mathrm{AC}$ & $\mathrm{AC} 1$ & $\begin{array}{l}\text { 17. Explanation of where } \\
\text { responsibility lies for climate change } \\
\text { policy and action } \\
18 \text {. Mechanism by which board } \\
\text { reviews company progress on climate } \\
\text { change actions. }\end{array}$ \\
\hline
\end{tabular}

Source: [6]

Multiple regression technique is used in this study. The regression equation is shown as follows.

GHGDisc $=\alpha+\beta_{1}$ PROF $+\beta_{2}$ PROP $+\beta_{3}$ SIZE $+\beta_{4}$ KINS $+e(1)$

Where profitability is measured (PROF) by dividing net income with total equity. PROPER rating (PROP) is measured by giving a score to each company color rating. The score are 1 for black/very poor, 2 for red/poor, 3 for blue/fair, 4 for green/good, and 5 for gold/very good. Firm size (SIZE) is measured using natural logarithm (Ln) from company total asset. Institutional ownership (KINS) is measured with institutional shares divided by the total number of circulating shares.

\section{Results and discussion}

Table 3 presents the percentage of each item disclose in GHG emissions disclosure. External verification (GH2) is the most revealed item by the company with $92 \%$, followed by an explanation of where responsibility lies for climate change policy and action (AC1) item with $68 \%$ disclosure and lastly, assessment of risks and opportunities (CC1) item with $60 \%$ for three consecutive years. However, there are two items which are a disclosure by facility or segment (GH6) and costs of future emissions factored in capital expenditure planning (RC4) that not disclosed by the companies during this study.
Table 3. The percentage of disclosure of each GHG emission item

\begin{tabular}{|c|c|c|c|c|c|}
\hline \multicolumn{3}{|c|}{ GHG Emissions Item } & \multirow{2}{*}{$\begin{array}{l}2015 \\
60 \%\end{array}$} & \multirow{2}{*}{\begin{tabular}{r|}
2016 \\
$60 \%$
\end{tabular}} & \multirow{2}{*}{$\begin{array}{l}2017 \\
60 \%\end{array}$} \\
\hline \multirow[t]{2}{*}{$\mathrm{CC}$} & $\mathrm{CC} 1$ & $\begin{array}{l}\text { 1. Assessment of } \\
\text { risks and } \\
\text { opportunities }\end{array}$ & & & \\
\hline & $\mathrm{CC} 2$ & $\begin{array}{l}\text { 2. Financial } \\
\text { implications }\end{array}$ & $24 \%$ & $20 \%$ & $24 \%$ \\
\hline \multirow{7}{*}{$\mathrm{GH}$} & GH1 & $\begin{array}{l}\text { 3. Methodology for } \\
\text { calculation }\end{array}$ & $36 \%$ & $36 \%$ & $36 \%$ \\
\hline & GH2 & $\begin{array}{l}\text { 4. External } \\
\text { verification }\end{array}$ & $92 \%$ & $92 \%$ & $92 \%$ \\
\hline & GH3 & 5. Total emissions & $52 \%$ & $52 \%$ & $56 \%$ \\
\hline & GH4 & $\begin{array}{l}\text { 6. Disclosure by } \\
\text { scope }\end{array}$ & $4 \%$ & $4 \%$ & $4 \%$ \\
\hline & GH5 & $\begin{array}{l}\text { 7. Disclosure by } \\
\text { source }\end{array}$ & $4 \%$ & $4 \%$ & $8 \%$ \\
\hline & GH6 & $\begin{array}{l}\text { 8. Disclosure by } \\
\text { facility or segment }\end{array}$ & $0 \%$ & $0 \%$ & $0 \%$ \\
\hline & GH7 & $\begin{array}{l}\text { 9. Historical } \\
\text { comparison of } \\
\text { emissions }\end{array}$ & $28 \%$ & $24 \%$ & $32 \%$ \\
\hline \multirow{3}{*}{$\mathrm{EC}$} & EC1 & 10. Total consumed & $52 \%$ & $56 \%$ & $56 \%$ \\
\hline & $\mathrm{EC} 2$ & $\begin{array}{l}\text { 11. Disclosure } \\
\text { consumption from } \\
\text { renewable source }\end{array}$ & $20 \%$ & $20 \%$ & $20 \%$ \\
\hline & EC3 & $\begin{array}{l}\text { 12. Disclosure by } \\
\text { type, facility, or } \\
\text { segment }\end{array}$ & $8 \%$ & $12 \%$ & $12 \%$ \\
\hline \multirow{4}{*}{$\mathrm{RC}$} & $\mathrm{RC} 1$ & $\begin{array}{l}\text { 13. Plans to reduce } \\
\text { GHG emissions }\end{array}$ & $32 \%$ & $32 \%$ & $36 \%$ \\
\hline & $\mathrm{RC} 2$ & $\begin{array}{l}\text { 14. Targets for } \\
\text { GHG emissions }\end{array}$ & $12 \%$ & $12 \%$ & $16 \%$ \\
\hline & $\mathrm{RC} 3$ & $\begin{array}{l}\text { 15. Reductions } \\
\text { achieved to date }\end{array}$ & $32 \%$ & $32 \%$ & $36 \%$ \\
\hline & $\mathrm{RC} 4$ & $\begin{array}{l}\text { 16. Costs of future } \\
\text { emissions factored } \\
\text { in capital } \\
\text { expenditure } \\
\text { planning }\end{array}$ & $0 \%$ & $0 \%$ & $0 \%$ \\
\hline \multirow{3}{*}{$\mathrm{AC}$} & $\mathrm{AC} 1$ & $\begin{array}{l}\text { 17. Explanation of } \\
\text { where } \\
\text { responsibility lies } \\
\text { for climate change } \\
\text { policy and action }\end{array}$ & $68 \%$ & $68 \%$ & $68 \%$ \\
\hline & $\mathrm{AC} 2$ & $\begin{array}{l}18 . \text { Mechanism by } \\
\text { which board } \\
\text { reviews company } \\
\text { progress on climate } \\
\text { change actions. }\end{array}$ & $20 \%$ & $20 \%$ & $20 \%$ \\
\hline & Mean & & $30 \%$ & $30 \%$ & $32 \%$ \\
\hline
\end{tabular}

The descriptive statistics of each variable are presented in Table 4. According to the results of descriptive statistics, the average GHG emission disclosure is $30.82 \%$. It shows that the disclosure of GHG emissions is still relatively low in sample companies with a minimum value of 0.1111 and a maximum value of 0.7778 . PROPER rating in sample companies shows that "red" is the lowest rating with a minimum value of 2 and "green" is the highest rating with a maximum value of 4 . On average, companies are in "blue" rating value of 3 . 
Table 4. Descriptive statistics

\begin{tabular}{|c|c|c|c|c|c|}
\hline Variable & $\mathbf{N}$ & $\begin{array}{c}\text { Mini } \\
\text { mum }\end{array}$ & $\begin{array}{c}\text { Maximu } \\
\mathbf{m}\end{array}$ & Mean & $\begin{array}{c}\text { Std. } \\
\text { Deviation }\end{array}$ \\
\hline PROF & 7 & $\begin{array}{c}0.000 \\
5\end{array}$ & 1.3585 & 0.217720 & $\begin{array}{c}0.300383 \\
7\end{array}$ \\
\hline PROP & $\begin{array}{c}7 \\
5\end{array}$ & $\begin{array}{c}2.000 \\
0\end{array}$ & 4.0000 & 3.093333 & $\begin{array}{c}0.524361 \\
5\end{array}$ \\
\hline SIZE & 7 & $\begin{array}{c}27.18 \\
5\end{array}$ & 32.1510 & $\begin{array}{c}29.67820 \\
8\end{array}$ & $\begin{array}{c}1.412997 \\
3\end{array}$ \\
\hline KINS & $\begin{array}{c}7 \\
5\end{array}$ & $\begin{array}{c}0.330 \\
7\end{array}$ & 0.9306 & 0.693948 & $\begin{array}{c}0.165026 \\
0\end{array}$ \\
\hline $\begin{array}{c}\text { GHGDis } \\
\text { c }\end{array}$ & $\begin{array}{c}7 \\
5\end{array}$ & $\begin{array}{c}0.111 \\
1\end{array}$ & 0.7778 & 0.308152 & $\begin{array}{c}0.189240 \\
4\end{array}$ \\
\hline
\end{tabular}

The classic assumption test results show that the data is normally distributed with the Kolmogorov Smirnov test significance value of 0.146. Another classic assumption test shows that there are no symptoms of multicollinearity with tolerance and VIF values of each variable $>0.1$ and $<10$ shown in Table 5 and the significance value of the run test is 0.295 , therefore, there is no problem with autocorrelation. Furthermore, the white test shows $\mathrm{c}^{2}$ count $<\mathrm{c}^{2}$ is $10.35<15.51$, therefore, heteroscedasticity symptom is not found.

Table 5. Multiple Regression and Multicollinearity

\begin{tabular}{|c|c|c|c|c|c|c|}
\hline \multicolumn{9}{|c|}{ Dariable } & $\begin{array}{c}\text { Dependent } \\
\text { Prediction }\end{array}$ & Coefficient & $\mathbf{t}$ & Sig & Tolerance & VIF \\
\hline Constant & & -0.059 & -0.158 & 0.875 & - & - \\
\hline PROF & + & 0.224 & 4.003 & 0.000 & 0.891 & 1.122 \\
\hline PROP & + & 0.196 & 6.064 & 0.000 & 0.878 & 1.139 \\
\hline SIZE & + & -0.001 & -0.048 & 0.962 & 0.874 & 1.144 \\
\hline KINS & + & -0.389 & -3.692 & 0.000 & 0.832 & 1.202 \\
\hline
\end{tabular}

Note. $\mathrm{R}^{2}=0,508 ;$ Adjusted $\mathrm{R}^{2}=0,480 ; \mathrm{p}$ value $=0,05$; $\mathrm{N}=75$.

The regression has an adjusted $\mathrm{R} 2$ of $48 \%$. The results of the hypothesis testing presented in Table 5 shows that there are 2 hypotheses accepted from the 4 hypotheses proposed. The specifics of the hypotheses testing results are as follows: First, Profitability (PROF) is shown to affect GHG emission disclosure (GHGDisc) with a coefficient (p-value) of $0.224(0.000)$. The result implies that high-profit companies possess more resources to perform responsibilities toward the environment, including GHG emission disclosure. It also shows that companies that have low profitability will need more improving their environmental responsibility activities compared to high-profit companies. This finding also suggests that companies with greater profitability produce a higher volume of GHG emission information would be useful to mitigate social pressure from the community; as a form of a positive signal and may enhance the relationship to the stakeholders. This result is in line with studies conducted by [6-9] that found that profitability positively affects GHG emission disclosure.

Second, table 5 indicates that there is a positive correlation between PROPER ratings obtained by a company with GHG emission disclosure. PROPER rating (PROP) is shown to affect GHG emission disclosure (GHGDisc.) where the coefficient (p-value) of $0.196(0.000)$, and thus, H2 is supported. This is in line with the stakeholder theory and also previous studies by $[10,11]$. The result implies that companies that have the highest PROPER rating will provide a better environmental performance of a company. Companies with highest PROPER ratings tend to disclose broader performance reports, including GHG emission disclosure compared to lowest rating PROPER. Even though it is voluntary in nature, it is well intended to provide information to stakeholders.

The third hypothesis stating that bigger companies will perform higher GHG emission disclosure compared to smaller companies. However, the relationship is not statistically significant with a coefficient (p-value) of 0.001 (0.962). Firm size (SIZE) is not a defining factor that encourages a company to perform GHG emission disclosure (GHGDisc). These findings are also consistent with previous studies [9]. The insignificant effect follows because large companies have responsibilities and capacities to disclose environmental corporate responsibility including GHG emission information tend to be profit-oriented at the expense of environmental performance. GHG emission disclosure is not a priority for many big companies. This finding is not consistent with previous studies by $[6,17]$.

Fourth, regression results in Table 5 show that there is a negative and statistically significant relationship between institutional ownership and GHG emission disclosure with a coefficient (p-value) of -0.389 (0.000). The negative value shows that the higher the institutional ownership of a company, the lower the GHG emission disclosure will be. Since the company with high institutional ownership is pressured by the stakeholders to gain as much profit as possible. This leads to cost efficiency where GHG emission disclosure might be affected. This finding is in line with stakeholder theory and also previous studies by $[17,18]$. On the other hand, another study found a positive correlation between ownership structure and environmental disclosure [16].

\section{Conclusion and Limitations}

This study examines the effect of company financial performance (profitability), company characteristics (PROPER rating, firm size, and institutional ownership) on GHG emission disclosure of companies listed in Indonesia Stock Exchange. The results deliver evidence that profitability, PROPER rating, and institutional ownership have an impact on GHG emission disclosure. On the other hand, this study failed to provide evidence that company size is a determinant of GHG emission disclosure. Disclose GHG emission disclosure may keep a good relationship with stakeholders. Furthermore, this study can be used by companies, investors, and regulators in formulating policies for decision making related to GHG emission disclosure.

Meanwhile, this study still has some limitations. First, most of the companies listed in IDX in the period year of 2015-2017 do not have PROPER rating. Besides, some companies do not have institutional ownership. These points significantly reduce the total number of the sample size. Future studies are expected to be able to use other variables that are thought to influence GHG 
emission disclosure such as government ownership and other factors.

\section{References}

1. J-M. Prado-Lorenzo, L. Rodriguez-Dominguez, I. Gallego-Alvarez, I-M. García-Sánchez, Factors influencing the disclosure of greenhouse gas emissions in companies world-wide, Management Decision 47, 1133-57 (2009)

2. C.I. Chu, B. Chatterjee, A. Brown, The current status of greenhouse gas reporting by Chinese companies: A test of legitimacy theory, Managerial Auditing Journal 28, 114-39 (2012)

3. Elsayih J, Tang Q and Lan Y-C, Corporate governance and carbon transparency: Australian experience Accounting Research Journal 31, 40522 (2018)

4. L. Liao, L. Luo, Q. Tang, Gender diversity, board independence, environmental committee and greenhouse gas disclosure, The British Accounting Review 47, 409-24 (2015)

5. W.I.F. Sri, B.M. Arief, Relationship between Company Financial Performance, Characteristic and Environmental Disclosure of ASX Listed Companies, E3S Web of Conferences: EDP Sciences), 10024 (2018)

6. B.B. Choi, D. Lee, J. Psaros An analysis of Australian company carbon emission disclosures, Pacific Accounting Review 25, 58-79 (2013)

7. Y. Lu, I. Abeysekera, Stakeholders' power, corporate characteristics, and social and environmental disclosure: evidence from China, Journal of Cleaner Production 64, 426-36 (2014)

8. L. Luo, Y.C. Lan, Q. Tang, Corporate incentives to disclose carbon information: Evidence from the CDP Global 500 report, Journal of International Financial Management \& Accounting 23, 93-120 (2012)

9. K.K. Gatimbu, J.M. Wabwire, Effect of Corporate Environmental Disclosure on Financial Performance of Firms Listed at Nairobi Securities Exchange, Kenya (2016)

10. H.S. Pradini, E. Kiswara, The Analysis of Information Content towards Greenhouse Gas Emissions Disclosure In Indonesia's Companies, Diponegoro Journal of Accounting, 736-47 (2013)

11. R.A. Prasetya, A. Yulianto, The Effects of Tax Avoidance, Accrual Earnings Management, Real Earnings Management, and Capital Intensity on the Cost of Equity, Jurnal Dinamika Akuntansi 10, 71-81 (2018)

12. W. Ben-Amar, P. McIlkenny, Board effectiveness and the voluntary disclosure of climate change information, Business Strategy and the Environment 24, 704-19 (2015)

13. E-H. Kim, T.P. Lyon, Strategic environmental disclosure: Evidence from the DOE's voluntary greenhouse gas registry, Journal of Environmental Economics and Management 61, 311-26 (2011)
14. C. Kuzey, A. Uyar, Determinants of sustainability reporting and its impact on firm value: Evidence from the emerging market of Turkey, Journal of cleaner production 143, 27-39 (2017)

15. J. Cotter, M.M. Najah, Institutional investor influence on global climate change disclosure practices, Australian journal of management 37, 169-87 (2012)

16. P-L. Ho, G. Tower Ownership structure and voluntary disclosure in corporate annual reports of Malaysian listed firms, Corporate Ownership and Control 8, 296-312 (2011)

17. K.K. Rao, C.A. Tilt, L.H. Lester, Corporate governance and environmental reporting: an Australian study, Corporate Governance: The international journal of business in society 12, 14363 (2012)

18. C. Krishnamurti, E. Velayutham, The influence of board committee structures on voluntary disclosure of greenhouse gas emissions: Australian evidence Pacific-Basin Finance Journal 50, 65-81 (2018) 